\title{
Evaluation of solar photovoltaic systems to shade cows in a pasture-based dairy herd
}

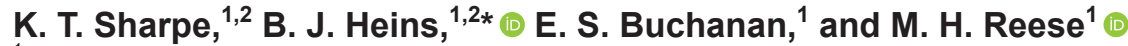 \\ ${ }^{1}$ West Central Research and Outreach Center, University of Minnesota, Morris 56267 \\ ${ }^{2}$ Department of Animal Science, University of Minnesota, St. Paul 55108
}

\begin{abstract}
The combined use of solar photovoltaics and agriculture may provide farmers with an alternative source of income and reduce heat stress in dairy cows. The objective of this study was to determine the effects on grazing cattle under shade from a solar photovoltaic system. The study was conducted at the University of Minnesota West Central Research and Outreach Center in Morris, Minnesota on a grazing dairy. Twenty-four crossbred cows were randomly assigned to 2 treatment groups (shade or no shade) from June to September in 2019. The replicated $(n=4)$ treatment groups of 6 cows each were provided shade from a $30-\mathrm{kW}$ photovoltaic system. Two groups of cows had access to shade in paddocks, and 2 groups of cows had no shade in paddocks. All cows were located in the same pasture during summer. Behavior observations and milk production were evaluated for cows during 4 periods of summer. Boluses and an eartag sensor monitored internal body temperature, activity, and rumination on all cows, respectively. Independent variables were the fixed effects of breed, treatment group, coat color, period, and parity, and random effects were replicate group, date, and cow. No differences in fly prevalence, milk production, fat and protein production, or drinking bouts were observed between the treatment groups. Shade cows had more ear flicks (11.4 ear flicks/30 s) than no-shade cows (8.6 ear flicks $/ 30 \mathrm{~s}$ ) and had dirtier bellies and lower legs (2.2 and 3.2, respectively) than no-shade cows (1.9 and 2.9 , respectively). During afternoon hours, shade cows had lower respiration rates (66.4 breaths $/ \mathrm{min}$ ) than no-shade cows (78.3 breaths/min). From 1200 to 1800 $\mathrm{h}$ and 1800 to $0000 \mathrm{~h}$, shade cows had lower body temperature (39.0 and $39.2^{\circ} \mathrm{C}$, respectively) than no-shade cows (39.3 and $39.4^{\circ} \mathrm{C}$, respectively). Furthermore, between milking times (0800 and $1600 \mathrm{~h}$ ), the shade cows had lower body temperature $\left(38.9^{\circ} \mathrm{C}\right)$ than no-shade
\end{abstract}

Received May 1, 2020.

Accepted October 13, 2020.

*Corresponding author: hein0106@umn.edu cows $\left(39.1^{\circ} \mathrm{C}\right)$. Agrivoltaics incorporated into pasture dairy systems may reduce the intensity of heats stress in dairy cows and increase well-being of cows and the efficiency of land use.

Key words: dairy, heat stress, pasture-based, solar photovoltaic

\section{INTRODUCTION}

Global warming has occurred on every continent, and greater than average warming has occurred over land than over oceans (Allen et al., 2018). Climate change is expected to cause greater than average maximum temperatures, greater than average minimum temperatures, and lower than average cool days. An increase in the duration and intensity of heat waves and droughts are also likely to occur in most land regions (IPCC, 2007).

Thermal balance is the difference between heat production and loss from metabolism and heat transfer with the outside environment (National Research Council, 1981). Increased temperatures decrease the amount of time cattle are in zones of thermal comfort, and heat stress typically occurs above $25^{\circ} \mathrm{C}$ for cows (West, 2003). Some producers may modify barns with heat abatement measures such as sprinklers and fans to make use of evaporative cooling techniques. However, for pasture-based dairy systems, heat abatement for cows may pose a challenge. As temperatures increase, cow cooling for pasture-based systems necessitates further exploration.

Heat stress has been estimated to cost the dairy industry in the United States more than $\$ 900$ million annually due to production losses (St-Pierre et al., 2003). The main contributors to heat stress are temperature, humidity, and temperature-humidity index (THI); THI is used to estimate effects of heat stress on milk production, nutrition, behavior, reproduction, and overall health of cows (Cook et al., 2007; Tucker et al., 2008). A THI of 68 to 72 has been reported to induce heat stress in cows and decrease milk production (Bohmanova et al., 2007; Becker et al., 2020), 
decrease fertility (García-Ispierto et al., 2006), and increase lameness in dairy cattle (Cook et al., 2007). Prior research has been conducted on heat abatement measures in freestall barns with sprinklers, evaporative cooling, and fan design (Chen et al., 2015; Drwencke et al., 2020). However, pasture-based research efforts on heat abatement are limited and have investigated fabric and trees for shade and sprinklers (Tucker et al., 2008; Schütz et at., 2009; Palacio et al., 2015).

Agrivoltaics is the combined use of solar photovoltaic (PV) and agricultural systems to provide mutual benefits for both the agricultural and energy industries (Hassanpour Adeh et al., 2018). Dupraz et al. (2011) determined that agrivoltaic systems have the potential to increase land productivity and efficiency by 60 to $70 \%$. Maia et al. (2020) used an agrivoltaic system to investigate the behaviors of sheep that had access to shade from solar panels or a shade cloth that blocked $80 \%$ of solar irradiation. The authors found benefits of shade for sheep and reported that the solar system provided a resource for generating electrical energy, and thus reduced the carbon footprint of the farm. No research in the scientific literature has investigated the use of shade from a ground-mounted solar PV system and the effects on dairy cows. The current study used a solar PV system for shade that was a permanent structure in the pasture, and the solar panels were not translucent compared with shade cloth, which may not be permanent in pasture and may allow some light through the cloth. The permanent solar system is ex- pected to be in the same location in the pasture for 25 to 30 yr with low or no maintenance. The solar photovoltaic system would also provide benefits of solar energy for the farm, whereas shade cloth would provide no energy generation.

The hypothesis of the current study was that shade from solar panels for dairy cows would reduce the intensity of heat stress indicated by reduced respiration rates, internal body temperatures, and drinking events. Therefore, the objective of this study was to investigate the effects of shade from solar PV on the production, health, and behavior of pastured dairy cows.

\section{MATERIALS AND METHODS}

\section{Experimental Design and Collection of Data}

The study was conducted at the University of Minnesota West Central Research and Outreach Center (WCROC) dairy farm in Morris, Minnesota. Animal care and management were approved by the University of Minnesota Institutional Animal Care and Use Committee (\#1709-35099A). The WCROC dairy maintains 300 cows in a low-input, grazing-based system. During the summer of 2018, a $30-\mathrm{kW}$ ground-mounted solar system was installed in a single pasture at the WCROC (Figure 1). To optimize solar energy collection, the panels were mounted at a $35^{\circ}$ angle facing due south. The Heliene solar panels (Heliene Photovoltaic Modules, Marie, Ontario) were mounted 2.4 to $3 \mathrm{~m}$ from

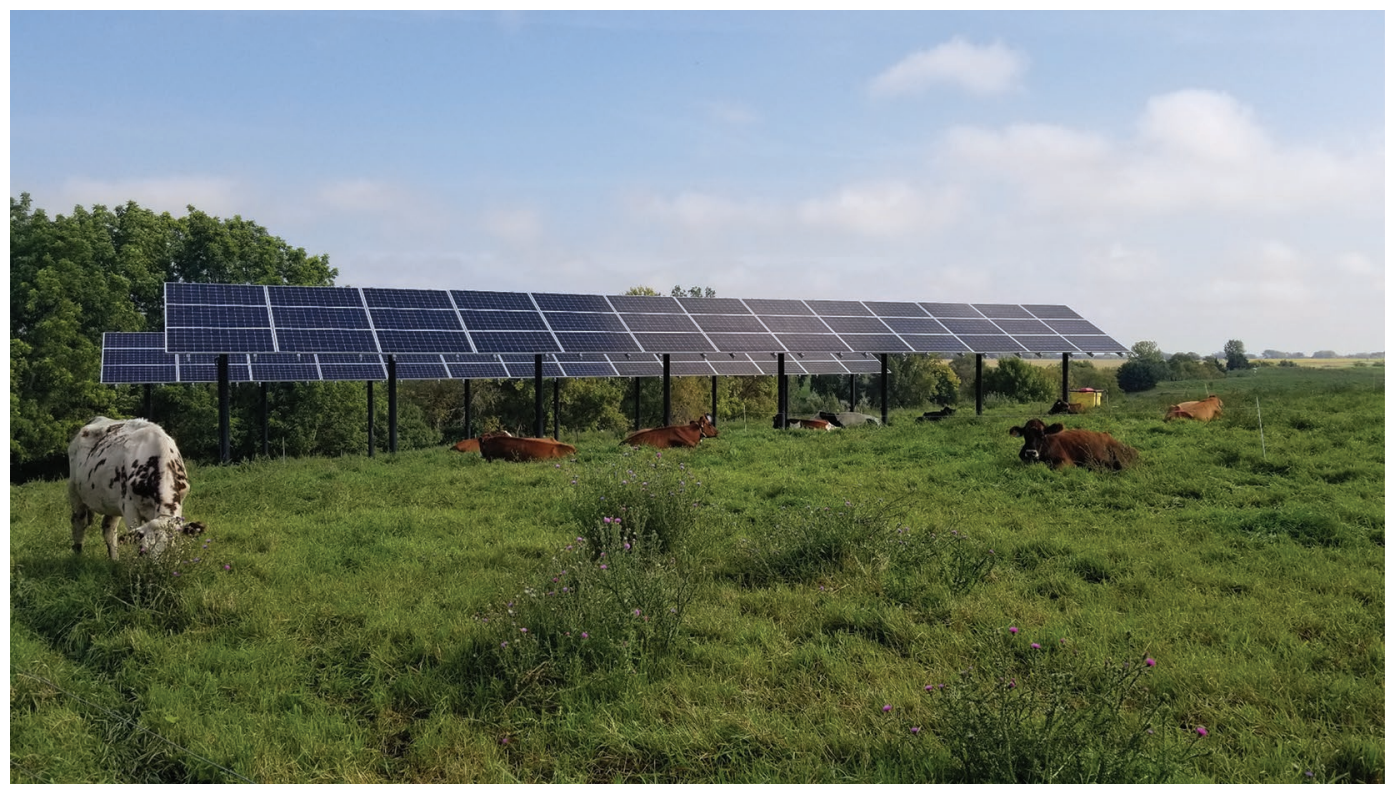

Figure 1. The 30-kW solar photovoltaic ground-mounted system for solar shading at the University of Minnesota West Central Research and Outreach Center in Morris, Minnesota. 
the ground so cows could not reach the panels. The solar system was a permanent fixture in the pasture and could not be moved to other pastures.

The study was conducted from June 2019 through September 2019. Twenty-four crossbred cows were enrolled and were randomly balanced across treatments by parity, breed group, DIM, and coat color. Crossbred cows were a mixture of Holstein, Montbéliarde, Viking Red, Jersey, and Normande breeds. All cows calved during the spring (March to May) of 2019. The cows were separated into 4 balanced and replicated groups, and each group had 6 cows. Replicated groups of 6 cows had an equal number of breed groups and parity and an equal number of cows determined to have either a minimum of $50 \%$ of a light-colored coat, $50 \%$ of a dark colored coat, or a mixture of both light and dark on their coats. Coat color was determined from photographs taken of the left and right side of each cow. Microsoft Paint software (Microsoft Corp., Redmond, WA) and visual analysis was used to determine the percentage of dark and light spots on the cows. The cow was determined to have a light coat color if over $50 \%$ of the coat was white or light colored. Dark colored coats were over $50 \%$ dark brown, black, or red. Mixed coats had an even amount of both dark and light coloring. The cows were from the certified organic herd at the WCROC and, during the study months, were required to be housed on pasture and to have at least 30\% DMI from pasture (USDA-NOP, 2019). All cows had access to $3,500 \mathrm{~kg}$ of DM per hectare from pasture, and forages were smooth bromegrass (Bromus inermis), orchardgrass (Dactylis glomerata), meadow fescue (Festuca pratensis), quackgrass (Elymus repens), red clover (Trifolium pratense), and kura clover (Trifolium ambiguum M. Bieb.). All cows were located in the same pasture; however, each group was provided a different paddock of $5,030 \mathrm{~m}^{2}$ in area. Cows were assigned to 1 of 2 treatments: shade or no shade. Shade cows had access to the shade from the solar PV system on pasture. The no-shade cows did not have access to any shade from trees or buildings while on pasture. All treatment groups were provided a water tank and ad libitum access to a trace mineral mix. No grain or TMR was offered to cows. The cows were milked from 0600 to $0800 \mathrm{~h}$ and from 1600 to $1800 \mathrm{~h}$. Before milking, cows were in a holding pen $(7 \times 10 \mathrm{~m})$ with rubber mats and 2 circular fans. Cows were in the holding area and in the milking parlor for approximately $30 \mathrm{~min}$ each for milking before returning to pasture, and all cows were subject to the same heat abatement in the holding area.

Cows were provided access to pasture with the shade and no-shade treatments during 4 periods of the summer. Period 1 was from June 3 to June 10, 2019; period 2 was from July 8 to July 12, 2019; period 3 was from August 12 to August 17, 2019; and period 4 was from September 16 to September 20, 2019. The study periods were chosen based on the rotational grazing management plan of the herd, and typically grazing starts in the Upper Midwest in late May or early June each year. The solar system was permanent in the pasture; therefore, cows were on the study pasture based on grass growth and rotation of pastures within the dairy herd. The study allowed approximately $30 \mathrm{~d}$ of regrowth to occur on pasture before cows returned to the grazing pasture with the solar system. The first period was $7 \mathrm{~d}$ because maximum grass growth occurs in pastures in the Upper Midwest in early June, and more grass was available for cows during the first period. The other periods were $5 \mathrm{~d}$ because of lower forage quantity in the pasture, and the cows would not have been able to graze for $7 \mathrm{~d}$ because of low forage availability for all cows in all groups. When cows were not on the study periods, they were combined with the remaining organic cows at the WCROC, which were housed on alternative pastures. The cows were with the same treatment groups during each period of the study.

\section{Weather Data}

Weather data were collected for each period during the study from the weather station at the WCROC located at $45^{\circ} 35^{\prime} 44^{\prime \prime} \mathrm{N}$ and $95^{\circ} 52^{\prime} 53^{\prime \prime} \mathrm{W}$ (HOBO RX3000 Data Logger and Weather Station, Onset Computer Corp., Bourne, MA; Table 1). Data recorded included temperature, relative humidity (\%), total precipitation, and solar irradiation $\left(\mathrm{W} / \mathrm{m}^{2}\right)$. The THI for each period was determined using the following equation from Kendall et al. $(2006)$ : THI $=(1.8 \times T+32)-[(0.55$ $-0.0055 \times \mathrm{RH}) \times(1.8 \times T-26)]$, where $T=$ air temperature $\left({ }^{\circ} \mathrm{C}\right)$ and $\mathrm{RH}=$ relative humidity $(\%)$.

\section{Behavioral and Biological Measurements}

Fly Counts and Fly Avoidance Behaviors. Four observers were trained to collect biological and behavioral measurements before the first study period. Before the initiation of the study, fly counts and fly avoidance behaviors, respiration, and hygiene scoring were agreed upon on site by 5 observers (an experienced animal scientist and the 4 observers that were conducting the visual observations for the study). These definitions were based on previous research studies and the training of the animal scientist (Sjostrom et al., 2019; Perttu et al., 2020). Fly counts on cows were recorded twice during the morning $(1000 \mathrm{~h})$ and twice during the evening $(1600 \mathrm{~h})$ observations. Stable flies on front and back legs were recorded as the mean number of stable flies per leg, horn flies per a cow's side, and face flies 


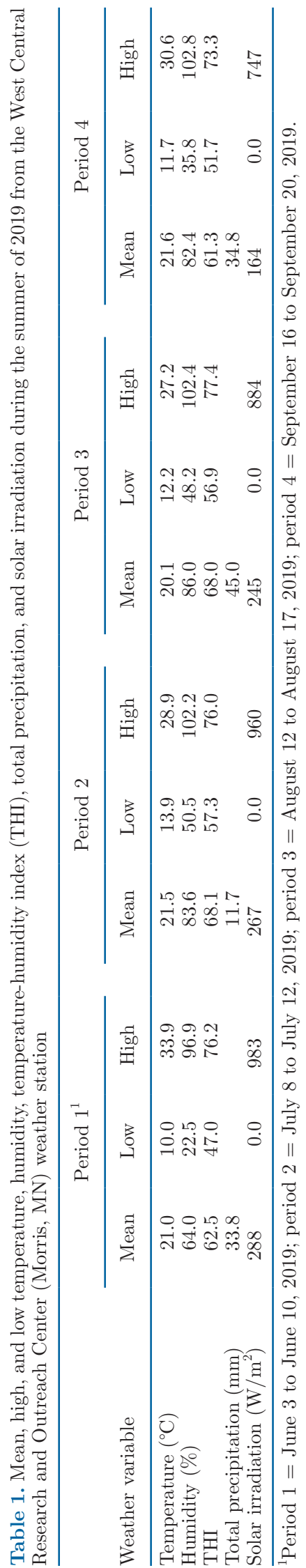

per a cow's face. Fly counts were made from a distance of $4 \mathrm{~m}$ (Kienitz et al., 2018; Perttu et al., 2020). Ten behavior observations were conducted twice per day on every cow: once in the morning and once in the afternoon. An observer watched each cow continuously for $30 \mathrm{~s}$ and recorded ear flicks, tail swishes, foot stomps, head tosses, and skin twitches.

Fly avoidance behaviors included head tosses, skin twitches, tail swishes, front leg stomps, and back leg kicks. A head toss was recorded if the animal's head was thrust back toward its body, far enough that the nose crossed an imaginary plane across the front of the cow's chest (Mullens et al., 2006). A skin twitch occurred if an isolated twitch took place in a localized area or as a continuous shiver over the whole flank for several seconds (Dougherty et al., 1995). A tail swish occurred if the tail was moved from its resting position to 1 side of the cow's body; a separate swish occurred if the tail crossed to the opposite side of the body (Dougherty et al., 1994). A front leg stomp was defined as a raising of either front leg (while standing) followed by a forceful thrust back to the ground. A hind leg kick occurred if either hind leg was thrust upward toward the cow's belly (Dougherty et al., 1995). Leg stomps and leg kicks were combined for analysis.

Respiration Rates, Hygiene Scores, and Production. Respiration rates of all cows were recorded once each morning $(1000 \mathrm{~h})$ and afternoon (1600 h). The same 4 observers counted the number of breaths for each cow for $30 \mathrm{~s}$ (flank movements/30 s; Nienaber et al., 2003). During afternoon observations, hygiene scores were recorded for each cow. The tailhead, upper leg (thigh), abdomen, udder, and lower hind leg were all scored for hygiene, with $1=$ clean to $5=$ dirty (Reneau et al., 2005). Daily milk production from individual cows was measured with a Boumatic Smart Dairy system (Madison, WI), and weekly measures of fat, protein, and SCC were recorded during each period of the study.

Sensors for Monitoring Body Temperature, Activity, and Rumination. All cows had a CowManager eartag sensor (CowManager SensOors, Agis, Harmelen, the Netherlands) that was mounted into a blank radio frequency identification tag and then placed on the right ear. Data from the sensor were transmitted wirelessly through a plug and play router or solar powered router to a base computer in the milking parlor and made available through a web-based application. The sensor classified data as ruminating, eating, not active, active, and high active behaviors (Pereira et al., 2018). Agis Automatisering BV (Agis, Harmelen, the Netherlands) provided processed hourly data from the CowManager sensor for ruminating, eating, not active, and active behaviors for all cows. 
HOBO Pendant G loggers (Onset Computer Corp.) were used to record lying time and standing time of all cows during the study periods. The loggers were programmed with logging intervals of $60 \mathrm{~s}$. The loggers were wrapped in a piece of SyrFlex (SyrVet Inc., Waukee, IA) cohesive bandage to reduce friction and attached to the right side of the right rear leg of each cow using SyrFlex bandage. The logger was oriented so that the $\mathrm{x}$-axis of the logger was parallel to the ground pointing toward the cow's head. The loggers tracked the $\mathrm{x}, \mathrm{y}$, and $\mathrm{z}$-axes on the cow, which converted into standing and lying behaviors. The loggers were attached to the cows during the morning milking of the first day of each study period and removed during the afternoon milking on the last day of each study period. After removal, the data were downloaded with Onset Hoboware software and exported to Microsoft Excel (Microsoft Corp., Redmond, WA). Daily lying times, frequency of lying bouts, and lying-bout duration were computed for each cow using a macro in SAS (SAS Institute, 2016) developed by N. Chapinal (Universtiy of British Columbia, Vancouver, BC, Canada).

SmaXtec boluses (smaXtec Classic Bolus, Graz, Austria) were administered orally to each cow 1 wk before the first study period (Ammer et al., 2016a). Boluses recorded internal body temperature and a proprietary activity measurement of the cows. Data from the boluses were downloaded by a repeater that transmitted data to the server located in the dairy barn office and stored data in an online database. Data were downloaded onto the server twice per day during the morning and afternoon milkings as each cow passed the repeater located in the milking parlor. Additionally, as the bolus resided in the reticulum, researchers were able to determine number of drinking bouts for each cow indicated by sharp drops in body temperature. Daily drinking bouts were an absolute number of drinking bouts classified from the smaXtec system that recorded the daily drinking bouts of cows. Data were downloaded weekly from the online server into Microsoft Excel.

Body temperature from the smaXtec bolus were analyzed in 1-h blocks throughout the day. Body temperature of shade and no-shade cows were measured during the hour blocks: (1) 0000 to $0600 \mathrm{~h}$, (2) 0600 to $1200 \mathrm{~h}$, (3) 1200 to $1800 \mathrm{~h}$, and (4) 1800 to $0000 \mathrm{~h}$. Furthermore, body temperatures were compared during the daylight hours between milking times (0800 and $1600 \mathrm{~h}$ ) and nighttime hours between milking times (1800 and $0600 \mathrm{~h}$ ). Last, body temperatures and activity were investigated during every hour of the day. Body temperature was analyzed in time blocks similar to Tucker at al. (2008) and Allen et al. (2015). Deviations from average daily body temperature of each cow were determined for each hour block during the study period.

Shade Use. For the cows in the shade treatment group, shade-use observations were conducted by locating cows every $10 \mathrm{~min}$ for two 180 -min periods to determine if cows were utilizing the solar shade. Shadeuse observations were recorded for one 180-min period in the morning and one 180-min period in the afternoon for a total of $6 \mathrm{~h} / \mathrm{d}$ of shade-use observations. Shadeuse methods were adapted from Tucker et al. (2008), and cows that had at least 1 hoof within the shadow from the solar panels or at least 1 hoof directly below the solar panels were recorded as using shade.

\section{Statistical Analysis}

Square root transformations of twice daily fly counts were used to satisfy analytical assumptions of equal variance and normal distribution of errors. The transformed fly count data were analyzed with PROC GLIMMIX in SAS (SAS Institute, 2016). Independent variables were the fixed effects of shade treatment, period, time of day, coat color, and the interaction of time of day by treatment with a Poisson distribution. The random effect was cow nested within replicated group by treatment with repeated measures.

Respiration rate per $30 \mathrm{~s}$ (measured twice daily) was multiplied by 2 to obtain the respiration rate for $1 \mathrm{~min}$. Data were analyzed with PROC MIXED of SAS (SAS Institute, 2016) with the fixed effects of treatment, coat color, period, time of day, and the interaction of time of day by treatment. Random effects were cow nested within replicated group by treatment and date nested within period.

Daily measures of hygiene scores and milk, fat, and protein production were analyzed with PROC MIXED of SAS (SAS Institute, 2016). The independent variables were the fixed effects of breed, parity, coat color, period, and treatment, and random effects were cow nested within replicated group by treatment and date with repeated measures. Daily drinking bouts were analyzed with PROC MIXED of SAS (SAS Institute, 2016). Fixed effects were coat color, treatment, period, and the interaction of treatment by period, and random effects were cow nested within replicated group by treatment and date. For analysis of lying behavior (daily lying time, number of lying bouts per day, and lying-bout duration), independent variables were fixed effects hour, period, treatment, and the interaction of treatment and hour and cow nested within replicated group by treatment as a random replicate effect.

For analysis of smaXtec daily body temperature and temperature deviation and CowManager activity, 
eating, and rumination, fixed effects were coat color, treatment, and period. Replicated group by treatment nested within cow and period nested within date were random effects. For the hour and hour block analysis of temperature and activity, fixed effects were coat color, treatment, period, hour, and the interaction of treatment by hour or hour block. The random effects were replicated group by treatment nested within cow and period nested within date with PROC MIXED of SAS (SAS Institute, 2016). Furthermore, separate regression analyses evaluated the effect of body temperature on air temperature, solar radiation, and THI independently. For all analyses, the autoregressive covariance [AR(1)] structure or compound symmetry covariance structure was used because it resulted in the lowest Akaike's information criterion (Littell et al., 1998). All results from all analyses were reported as least squares means, with significance declared at $P<0.05$.

\section{RESULTS AND DISCUSSION}

\section{Weather Data}

Weather data for all periods of the study are summarized in Table 1. The THI were low compared with other studies that involve heat stress, especially from the Southwest and Southeast in the United States. In the Upper Midwest, the evenings are cooler; therefore, the cows in the study may not have experienced heat stress during the evening hours. Also, some cows may not have experienced heat stress in the study because of the low THI. Becker and Stone (2020) reported that recent research has indicated that a THI of 68 induced heat stress in dairy cattle. Therefore, cows in the cur- rent study experienced mild heat stress as all recorded THI values were between 73.3 and 77.4.

\section{Fly Avoidance Behaviors, Fly Counts, and Respiration Rates}

Table 2 highlights least squares means and standard errors of means for fly avoidance behaviors, stable, face, and horn fly counts, and respiration rates for shade and no-shade cows for morning and afternoon observations. The shade and no-shade cows were similar $(P>0.10)$ for tail swish, foot stomp, head toss, and skin twitch behaviors during the morning and afternoon observations. During the afternoon observations, the number of ear flicks was greater $(P<0.05)$ for the shade cows than for the no-shade cows. Furthermore, shade and no-shade cows had similar $(P>0.10)$ number of stable flies, face flies, and horn flies during the morning and afternoon hours. Kendall et al. (2007) found no differences in hoof stomps and tail flicks for shade versus no-shade cows. Similar to the current study, Palacio et al. (2015) found no differences in fly intensity between shade and no-shade cows. As the shade and no-shade cows were located in the same pasture, it was hypothesized that no differences were found in fly counts or the majority of fly avoidance behaviors because the flies were easily able to transfer between each group of cows.

Respiration rates for shade and no-shade cows were similar $(P>0.10)$ during the morning hours. (Table $2)$. However, during the afternoon, the shade cows had lower $(P<0.05)$ respiration rates than no-shade cows. Similar to the current study, Kendall et al. (2007) found that cows with no access to a shade structure had greater respiration rates than cows with access

Table 2. Least squares means and SEM for fly avoidance behaviors, number of stable, face, and horn flies, and respiration rates for shade and no-shade cows during the morning and afternoon

\begin{tabular}{|c|c|c|c|c|c|c|c|c|}
\hline Measurement & \multicolumn{4}{|c|}{ Morning } & \multicolumn{4}{|c|}{ Afternoon } \\
\hline \multicolumn{9}{|l|}{ Behavior } \\
\hline Tail swish (count/30 s) & 8.4 & 1.9 & 11.1 & 2.6 & 7.8 & 1.8 & 11.6 & 2.7 \\
\hline Foot stomp (count/30 s) & 3.6 & 0.5 & 3.9 & 0.6 & 4.6 & 0.7 & 5.2 & 0.8 \\
\hline Ear flick (count/30 s) & 13.2 & 1.1 & 11.5 & 1.0 & $11.4^{\mathrm{a}}$ & 1.0 & $8.6^{\mathrm{b}}$ & 0.7 \\
\hline \multicolumn{9}{|l|}{ Fly count } \\
\hline Stable flies (flies/leg) & 11.4 & 0.04 & 10.9 & 0.03 & 12.2 & 0.04 & 12.9 & 0.04 \\
\hline Face fly (flies/face) & 2.6 & 0.01 & 1.1 & 0.01 & 3.1 & 0.01 & 1.0 & 0.01 \\
\hline Horn fly (flies/side) & 28.8 & 0.2 & 21.9 & 0.1 & 24.7 & 0.2 & 17.9 & 0.1 \\
\hline Total flies & 62.9 & 0.2 & 52.9 & 0.2 & 61.7 & 0.2 & 53.1 & 0.2 \\
\hline Respiration rates (breaths/min) & 50.9 & 3.5 & 52.5 & 3.4 & $66.4^{\mathrm{a}}$ & 3.4 & $78.3^{\mathrm{b}}$ & 3.3 \\
\hline
\end{tabular}

\footnotetext{
${ }^{\mathrm{a}, \mathrm{b}}$ Means within a row by time of day with different superscripts are different at $P<0.05$.
} 
to shade. Furthermore, Hahn et al. (1997) found that respiration rates under 60 breaths/min in dairy cows were indicative of minimal to no thermal stress, which indicated that both the shade and no-shade cows in the current study experienced heat stress conditions during the afternoon.

\section{Hygiene and Production}

The shade and no-shade cows had similar $(P>0.10)$ tailhead, upper leg, and udder hygiene scores (Table 3). However, the shade cows had $(P<0.05)$ dirtier bellies and lower legs (2.2 and 3.2, respectively) than did noshade cows (1.9 and 2.9, respectively). Shade cows used the shade for resting times during the study period, and as the cows defecated and urinated directly under the panels, bellies and lower legs became dirty as cows laid down to rest. The cooler and wetter ground under the solar panels combined with the reduced spread of cows furthered the dirtier conditions. Milk, fat, and protein production and SCC were not different $(P>0.10)$ between shade and no-shade cows (Table 3). Quite possibly, no difference was observed for milk production between treatment groups because cows were only under the shade for $22 \mathrm{~d}$ during the summer and for 5 or $7 \mathrm{~d}$ during each study period. Additionally, the numerically greater production of the no-shade cows may have been observed because the no-shade cows may have grazed longer during the day and evening hours, while the shade cows were standing underneath the solar panels and not grazing and eating. Additional research should evaluate long-term effects of production with more observations to determine if production of cows will be affected through shade structures in pastures of grazing cattle. Long-term effects of milk production and SCC may have been observed had cows been under the shade for the entire summer. Kendall et al. (2007) reported no difference in daily milk production between shade (14.0 $\mathrm{kg} / \mathrm{d})$ and no-shade $(13.2 \mathrm{~kg} / \mathrm{d})$ cows in New Zealand. Furthermore, Muller et al. (1994) found no difference in milk production or fat and protein in milk between shade and no-shade cows in South Africa.

\section{Drinking Bouts, Activity, Eating, Rumination, and Lying Time}

Results for drinking bouts per day from smaXtec bolus; activity, eating, and ruminating behaviors from CowManager ear tag; and lying and standing time from HOBO Loggers for shade and no-shade cows are in Table 4 . The number of daily drinking bouts were similar $(P>0.10)$ between shade and no-shade cows. Hourly activity, eating, rumination, and no activity across a 24-h period from the CowManager eartag were similar
Table 3. Least squares means and SEM for hygiene, hock lesion, and locomotion scores; production; and fat and protein content of milk for shade and no-shade cows

\begin{tabular}{lccccc}
\hline & \multicolumn{2}{c}{ Shade } & & \multicolumn{2}{c}{ No shade } \\
\cline { 2 - 3 } \cline { 5 - 6 } Measurement & LSM & SE & & LSM & \multirow{2}{*}{ SE } \\
\hline Hygiene score $^{1}$ & 3.0 & 0.2 & & 3.2 & 0.2 \\
Tail head & 2.4 & 0.1 & & 2.2 & 0.1 \\
Upper leg & $2.2^{\mathrm{a}}$ & 0.1 & & $1.9^{\mathrm{b}}$ & 0.1 \\
Belly & 2.2 & 0.1 & & 2.2 & 0.1 \\
Udder & $3.2^{\mathrm{a}}$ & 0.1 & & $2.9^{\mathrm{b}}$ & 0.1 \\
Lower leg & 13.9 & 1.5 & & 15.5 & 1.5 \\
Milk production (kg) & 4.1 & 0.2 & & 3.9 & 0.2 \\
Fat (\%) & 3.1 & 0.1 & & 3.1 & 0.1 \\
Protein (\%) & 4.0 & 0.1 & & 4.4 & 0.1 \\
SCC (cells/mL) & & & & & \\
\hline
\end{tabular}

${ }^{\mathrm{a}, \mathrm{b}}$ Means within a row with different superscripts are different at $P<$ 0.05 .

${ }^{1} 1=$ clean to $5=$ dirty.

$(P>0.10)$ for shade and no-shade cows. However, the shade cows had lower $(P<0.05)$ high activity $(6.7$ $\mathrm{min} / \mathrm{h})$ than did no-shade cows $(7.8 \mathrm{~min} / \mathrm{h})$. This could be due to bunching behavior that cattle exhibit, which is thought to reduce radiant heat absorption as cattle provide shade for each other (Lefcourt and Schmidtmann, 1989). Furthermore, shade cows may have had lower stress, and consequently exhibited less bunching behavior and greater high activity. Shade cows may have had less bunching because the area under the shade was large and allowed cows to spread out under the solar panels.

Across all periods of the study, the shade cows and no-shade cows had similar $(P>0.10)$ lying $(51.1 \mathrm{~min} / \mathrm{h}$ and $51.4 \mathrm{~min} / \mathrm{h}$, respectively) and standing time (8.9 $\mathrm{min} / \mathrm{h}$ and $8.6 \mathrm{~min} / \mathrm{h}$, respectively). Palacio et al. (2015) also found no difference in lying times across a study period between shade and no-shade cows. Figure

Table 4. Least squares means and SEM for drinking bouts per day from smaXtec bolus (smaXtec Classic Bolus, Graz, Austria); activity, eating, and ruminating behaviors from CowManager SensoOr (Agis, Harmelen, the Netherlands) and lying and standing time from HOBO Loggers (Onset Computer Corp., Bourne, MA) for shade and no-shade cows

\begin{tabular}{|c|c|c|c|c|}
\hline \multirow[b]{2}{*}{ Measurement } & \multicolumn{2}{|c|}{ Shade } & \multicolumn{2}{|c|}{ No shade } \\
\hline & LSM & $\mathrm{SE}$ & LSM & SE \\
\hline Daily drinking bouts & 4.4 & 0.4 & 3.7 & 0.4 \\
\hline High activity $(\min / \mathrm{h})$ & $6.7^{\mathrm{a}}$ & 0.3 & $7.8^{\mathrm{b}}$ & 0.3 \\
\hline Activity $(\mathrm{min} / \mathrm{h})$ & 5.6 & 0.8 & 7.5 & 0.8 \\
\hline Eating $(\min / \mathrm{h})$ & 21.3 & 0.8 & 19.7 & 0.9 \\
\hline Ruminating $(\mathrm{min} / \mathrm{h})$ & 17.3 & 0.7 & 17.6 & 0.7 \\
\hline No activity $(\mathrm{min} / \mathrm{h})$ & 9.4 & 0.5 & 7.5 & 0.5 \\
\hline Lying time $(\min / \mathrm{h})$ & 51.1 & 0.4 & 51.4 & 0.4 \\
\hline Standing time $(\mathrm{min} / \mathrm{h})$ & 8.9 & 0.4 & 8.6 & 0.4 \\
\hline
\end{tabular}

$\overline{\mathrm{a}, \mathrm{b}}$ Means within a row with different superscripts are different at $P<$ 0.05 . 


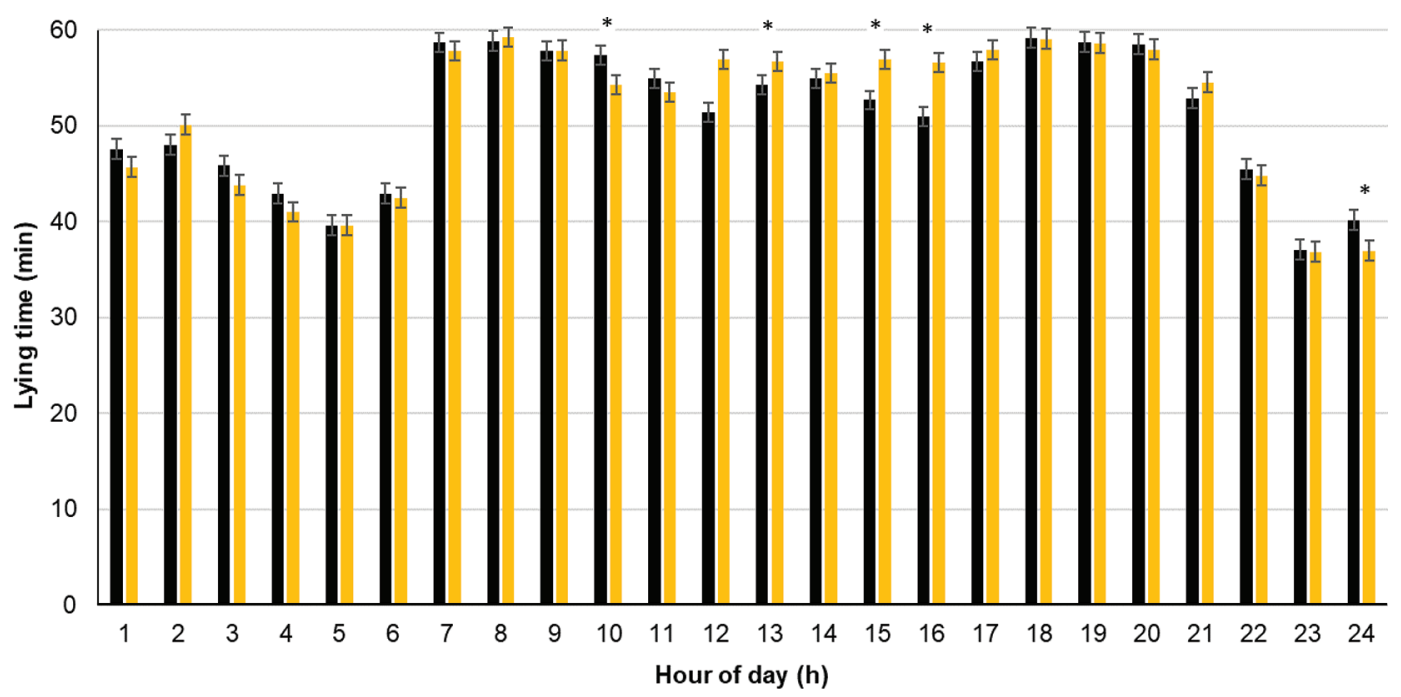

Figure 2. Least squares means and SEM for lying time by hour of day for shade cows (black) and no-shade cows (yellow). *Means within an hour of day for treatment groups are different at $P<0.05$.

2 has mean lying time for shade and no-shade cows across a 24 -h period. The shade cows had greater $(P$ $<0.05$ ) lying times during 1000 and $2400 \mathrm{~h}$ than did no-shade cows. Conversely, no-shade cows had greater $(P<0.05)$ lying times during 1300, 1500, and $1600 \mathrm{~h}$ than did shade cows. Allen et al. (2015) found that hour of the day affected lying and standing times of cows exposed to mild and moderate heat stress; they reported that cows that had greater body temperatures and were more heat stressed tended to have lower lying times. Cows in the current study tended to lay less during the hottest parts of the day, and standing time peaked between 1200 to $1800 \mathrm{~h}$. The greater lying time observed in the current study of the no-shade treatment cows during 1500 and $1600 \mathrm{~h}$ could be because the no-shade cows were fatigued after standing during the previous hours. Allen et al. (2015) also found that cows were more willing to lie down during $1600 \mathrm{~h}$, which was observed in the current study.

Figure 3 depicts mean hourly rumination, and Figure 4 depicts average hourly eating from the CowManager ear tag during a 24-h period. During 0200, 0300, 0400, 0900, 1500, and $2200 \mathrm{~h}$, shade cows had lower $(P<$ $0.05)$ rumination than did no-shade cows. However, the shade cows had greater $(P<0.05)$ rumination than no-shade cows during 1300 and $1700 \mathrm{~h}$. Rumination of shade cows was greater than no-shade cows during $1300 \mathrm{~h}$, which was one of the hottest parts of the day. During 0100, 0200, 0300, 1200, 1500,1600, 1900, and $2200 \mathrm{~h}$, shade cows had greater $(P<0.05)$ eating time than did no-shade cows (Figure 4). Conversely, during 1300, 1700, and $2300 \mathrm{~h}$, no-shade cows had more $(P<$ $0.05)$ eating time than did shade cows. Hourly activity data from the CowManager ear tag (Figure 5) found no-shade cows were more active $(P<0.05)$ than shade cows during 0100, 0200, 0300, 1300, 1400, 1500, 1700, and $2400 \mathrm{~h}$. Again, this could be due to no-shade cows that exhibited bunching behavior or more frequent standing and lying bouts.

\section{Shade Use}

Least squares means for shade use for the shade cows are shown in Table 5. Results are presented as the number of minutes per hour observed under the solar panels. During period 1, cows had more time not in the shade $(P<0.05)$ than in the shade. Similarly, during period 3 , cows had more $(P<0.05)$ minutes not in the shade than in the shade. During period 4 , cows had more $(P<0.05)$ minutes not in the shade than in the shade. Cows had similar times for shade and no-shade use during period 2. Period 2 had the highest mean temperature and humidity, THI, and high solar radiation. For daily use of the shade, results were extrapolated to a daily basis and showed that cows used the solar system $41 \%$ of the day, compared with $59 \%$ of the day when they did not use the solar panels. Similarly, Tucker et al. (2008) found that cows had more time under shade on days with greater solar radiation levels, greater ambient air temperatures, and greater THI. In the current study, cows spent $38 \%$ (period 1) to $44 \%$ (period 2) of the time in the shade during the observation periods. The percent of time cows used shade in this study was slightly greater than that found in Schütz et al. (2009), which found cows used shade 30\% of the time during the observation period. Tucker et al. 
(2008) found shade use by cows ranged from 0 to $54 \%$ of total daily time. Possibly, shade cows had more time under the shade in the current study compared with prior studies due to greater mean temperatures, THI, and solar radiation observed in this study.

\section{Body Temperature from SmaXtec}

Least squares means for body temperature and temperature deviation of cows from smaXtec bolus during specific periods during the day for shade and no-shade cows are in Table 6. From 0000 to 1200 h, body temperatures of shade and no-shade cows were similar $(P>$ 0.10). During 1200 to $1800 \mathrm{~h}$ and from 1800 to $0000 \mathrm{~h}$, shade cows had body temperatures of 39.0 and $39.2^{\circ} \mathrm{C}$, respectively. Furthermore, during the daytime, shade cows had lower $(P<0.05)$ body temperatures $\left(38.9^{\circ} \mathrm{C}\right)$ than no-shade cows $\left(39.1^{\circ} \mathrm{C}\right)$. Shade and no-shade cows had similar $(P>0.10)$ body temperatures at nighttime. For the current study, cows were observed with greater body temperatures during the daytime hours compared with the evening hours. In the Upper Midwest, evenings are cooler in ambient temperature, and humidity is typically reduced. Therefore, higher body temperatures of cows were observed during the daytime because of increased humidity during the daytime hours. During the evening hours, cows should dissipate their heat load because of the cooler weather in the evening in the Upper Midwest. Tucker et al. (2008) found that shaded cows had lower minimum body temperatures than nonshaded cows, and that body temperatures of cows increased as daily solar radiation increased. However, in disagreement with the current study, Tucker et al. (2008) found no differences in body temperatures between shade cows and no-shade cows during the daytime between milkings, quite possibly due to differing climates compared with the current study. The results agree with Schütz et al. (2009) and Ammer et al. (2016b), who found cow body temperatures to be greater with increased THI and ambient air temperatures. The temperature deviation from the average mean temperature of a cows was greater $(P<$ $0.05)$ for no-shade cows during the early morning (0000 to $0600 \mathrm{~h})$ and evening hours $(1800$ to $2400 \mathrm{~h})$. The deviations were greater $(P<0.05)$ for no-shade cows during the 0600 to $1800 \mathrm{~h}$ compared with the shade cows. Both treatment groups experienced an increase in internal body temperature during the daytime hours; however, the no-shade cows had a greater deviation from average compared with the shade cows. This may indicate that the no-shade cows experienced more heat stress during the day because no heat stress abatement were available to the no-shade cows.

Hourly body temperature results showed that noshade cows had greater $(P<0.05)$ body temperatures than shade cows during 1300 through $2300 \mathrm{~h}$ (Figure $6)$. On average, the difference in body temperature from 1300 to $2300 \mathrm{~h}$ between shade and no-shade cows was $0.5^{\circ} \mathrm{C}$. This follows daily trends of increased solar radiation and air temperatures between hours 1200 to 1600 in Minnesota (PVWatts, 2019). The reduced body temperature of the shade cows indicated a reduction

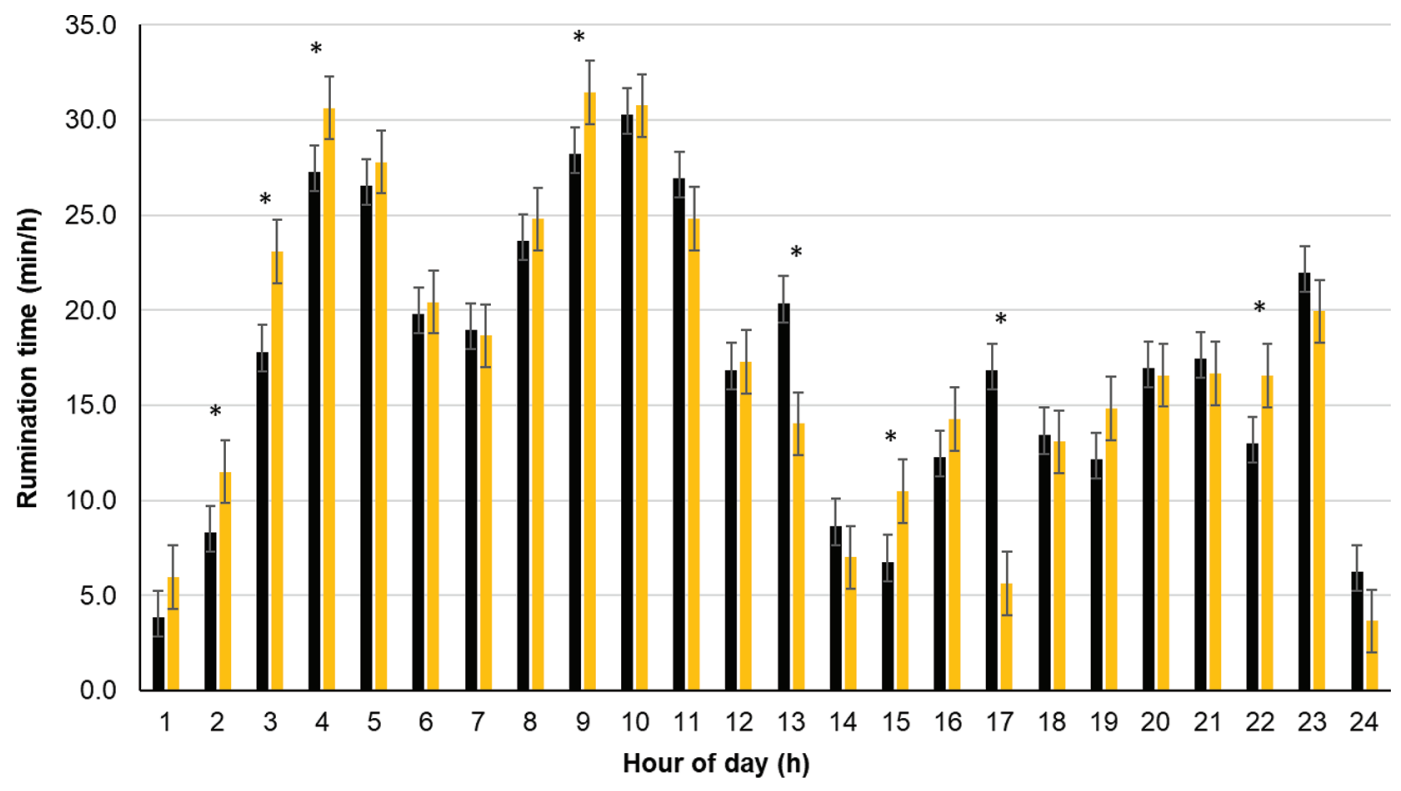

Figure 3. Least squares means and SEM for rumination minutes per hour from CowManager sensor (Agis, Harmelen, the Netherlands) for shade (black) and no-shade cows (yellow). ${ }^{*}$ Means within an hour of day for treatment groups are different at $P<0.05$. 


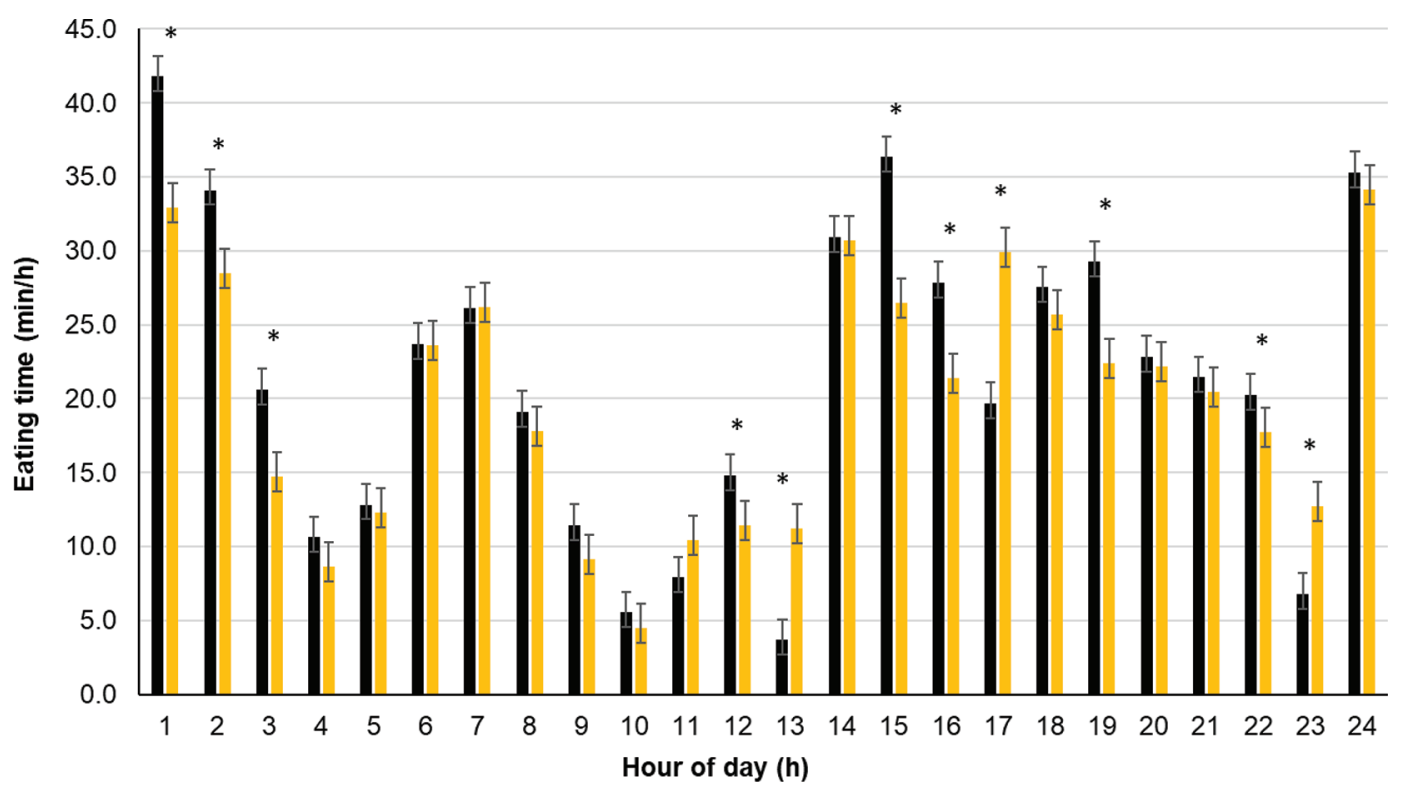

Figure 4. Least squares means and SEM for eating minutes from CowManager sensor (Agis, Harmelen, the Netherlands) per hour for shade (black) and no-shade cows (yellow). ${ }^{*}$ Means within an hour of day for treatment groups are different at $P<0.05$.

in heat stress during the hottest times of the day. The results indicated that solar shade may be an effective method to reduce heat stress in pastured cows. More research is needed to determine body temperature thresholds in dairy cattle to determine if $0.5^{\circ} \mathrm{C}$ may decrease reproductive performance, reduce milk production, decrease fat and protein content in milk, and increase SCC.
Regression coefficients of cow body temperature and air temperature in the current study found that for every $1^{\circ} \mathrm{C}$ increase in air temperature, body temperature of cows increased by $0.028^{\circ} \mathrm{C}$. For no-shade cows, this would have resulted in a $0.041^{\circ} \mathrm{C}$ increase in body temperature $(P<0.001)$. For shade cows, a $1^{\circ} \mathrm{C}$ increase in air temperature increased body temperature by $0.015^{\circ} \mathrm{C}(P<0.001)$, which is lower than the 0.041

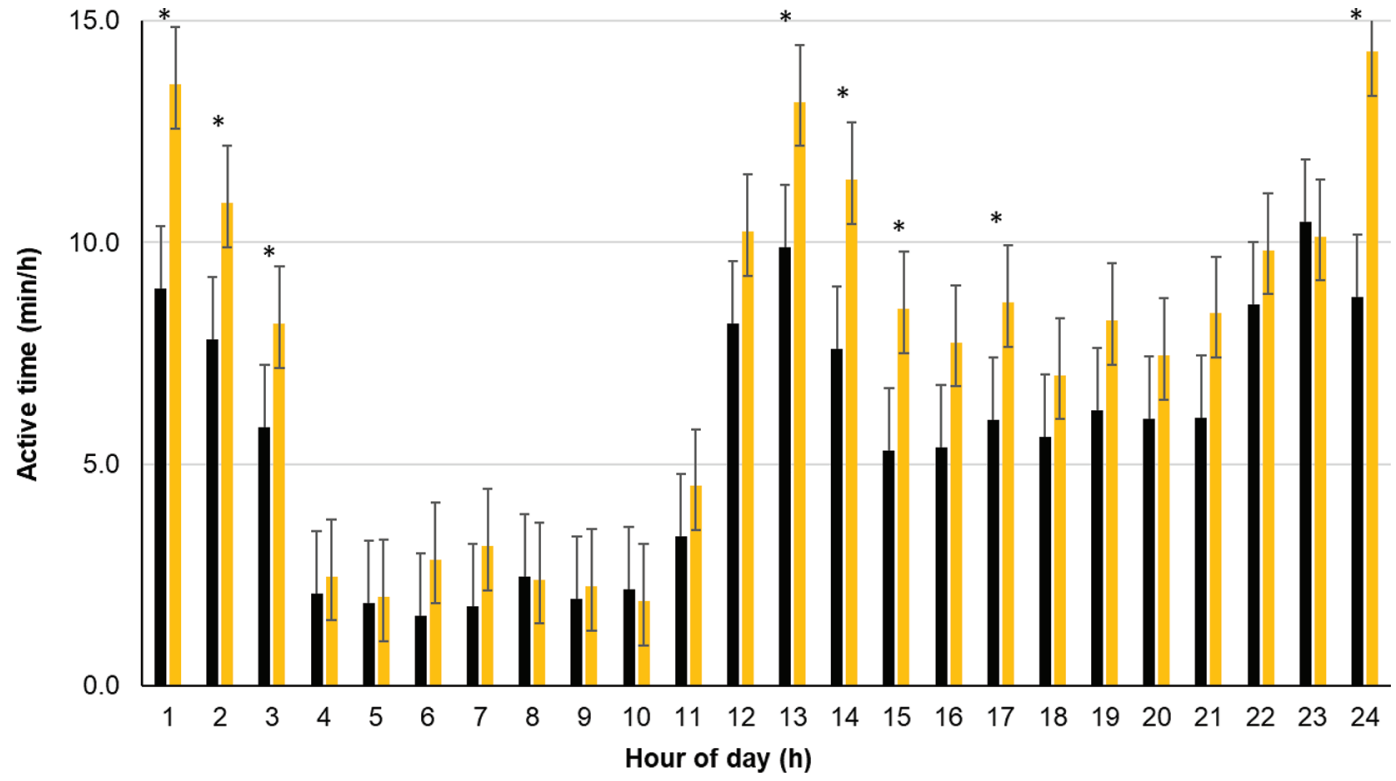

Figure 5. Least squares means and SEM for active minutes from CowManager sensor (Agis, Harmelen, the Netherlands) per hour for shade (black) and no-shade cows (yellow). ${ }^{*}$ Means within an hour of day for treatment groups are different at $P<0.05$. 
Table 5. Least squares means and SEM of shade use for shade cows only per 3 -h observation period per day

\begin{tabular}{llllll}
\hline & \multicolumn{2}{c}{$\begin{array}{c}\text { Use of shade } \\
(\mathrm{min} / \mathrm{h})\end{array}$} & & \multicolumn{2}{c}{$\begin{array}{c}\text { No use of shade } \\
(\mathrm{min} / \mathrm{h})\end{array}$} \\
\cline { 2 - 3 } \cline { 5 - 6 } Period & LSM & SE & & LSM & SE \\
\hline 1 & $22.9^{\mathrm{a}}$ & 2.3 & & $37.1^{\mathrm{b}}$ & 2.3 \\
2 & 28.5 & 2.3 & & 31.5 & 2.3 \\
3 & $23.9^{\mathrm{a}}$ & 2.3 & & $36.1^{\mathrm{b}}$ & 2.3 \\
4 & $23.4^{\mathrm{a}}$ & 2.3 & & $36.6^{\mathrm{b}}$ & 2.3 \\
\hline
\end{tabular}

a,b Means within a row with different superscripts are different at $P<$ 0.05 . for the no-shade cows. Furthermore, for every 1-unit increase in THI, no-shade cows increased $0.27^{\circ} \mathrm{C}(P<$ $0.001)$ in body temperature, and shade cows increased $0.011^{\circ} \mathrm{C}(P<0.001)$ in body temperature. Last, for every $1 \mathrm{~W} / \mathrm{m}^{2}$ increase in solar radiation, no-shade cows increased body temperature by $0.00016^{\circ} \mathrm{C}(P<$ $0.001)$. Interestingly, shade cows decreased $0.00001^{\circ} \mathrm{C}$ $(P<0.001)$ in body temperature for every $1 \mathrm{~W} / \mathrm{m}^{2}$ increase in solar radiation, which indicated the shade cows were seeking protection from the sun. Increases in air temperature, humidity, and THI need to remain

Table 6. Least squares means and SEM for body temperature and temperature deviations of cows from smaXtec bolus (smaXtec Classic Bolus, Graz, Austria) during specific periods during the day for shade and no-shade cows

\begin{tabular}{|c|c|c|c|c|c|c|c|c|}
\hline \multirow{2}{*}{ Time of day ${ }^{1}$} & \multicolumn{4}{|c|}{ Body temperature $\left({ }^{\circ} \mathrm{C}\right)$} & \multicolumn{4}{|c|}{ Temperature mean deviation $\left({ }^{\circ} \mathrm{C}\right)$} \\
\hline & \multicolumn{2}{|c|}{ Shade } & \multicolumn{2}{|c|}{ No shade } & \multicolumn{2}{|c|}{ Shade } & \multicolumn{2}{|c|}{ No Shade } \\
\hline 0000 to $0600 \mathrm{~h}$ & 39.0 & 0.1 & 39.0 & 0.1 & $-0.27^{\mathrm{a}}$ & 0.02 & $-0.31^{\mathrm{b}}$ & 0.02 \\
\hline 0600 to $1200 \mathrm{~h}$ & 38.7 & 0.1 & 38.7 & 0.1 & $-0.05^{\mathrm{a}}$ & 0.02 & $0.06^{\mathrm{b}}$ & 0.02 \\
\hline 1200 to $1800 \mathrm{~h}$ & $39.0^{\mathrm{a}}$ & 0.1 & $39.3^{\mathrm{b}}$ & 0.1 & $0.36^{\mathrm{a}}$ & 0.02 & $0.49^{\mathrm{b}}$ & 0.02 \\
\hline Nighttime & 39.1 & 0.1 & 39.2 & 0.1 & $-0.17^{\mathrm{a}}$ & 0.01 & $-0.08^{\mathrm{b}}$ & 0.01 \\
\hline
\end{tabular}

${ }_{\mathrm{a}, \mathrm{b}}$ Means within a row by hour block with different superscripts are different at $P<0.05$.

${ }^{1}$ Daylight between milkings $=0800-1600 \mathrm{~h}$; nighttime between milkings $=1800-0600 \mathrm{~h}$; during milkings $=0600-0800 \mathrm{~h}$ and $1600-1800 \mathrm{~h}$.

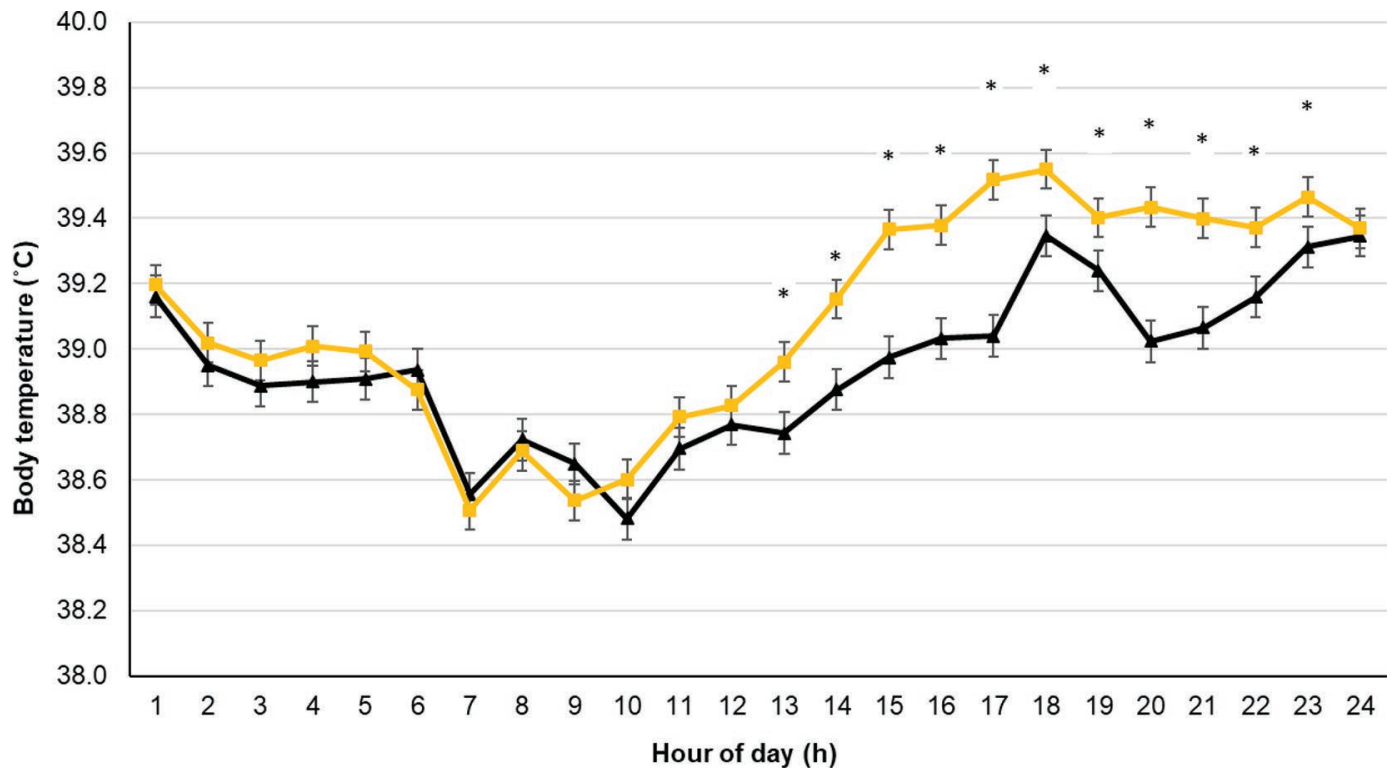

Figure 6. Least squares means and SEM for body temperature from smaXtec boluses (smaXtec Classic Bolus, Graz, Austria) by hour of day for shade cows (black) and no-shade cows (yellow). ${ }^{*}$ Means within an hour of day for treatment groups are different at $P<0.05$. 
high for a long period of time to potentially affect the cow from a more biological and long-lasting standpoint. The findings of no-shade cows in the current study are similar to those of Tucker et at. (2008), who found a positive relationship between solar radiation and mean cow body temperature.

\section{CONCLUSIONS}

Future research should be conducted on the effect of climate change on heat stress in pastured dairy cows as well as heat abatement techniques, especially within pasture-based systems and in different locations. Furthermore, research should investigate whether shadeuse during the hottest hours of the day is more or less beneficial to the cow than grazing. Complete pasture coverage by PV systems may allow for simultaneous grazing and cooling of cows. Agrivoltaics may provide an acceptable method of heat abatement to pastured dairy cows, although more long-term studies should be conducted to gain a clearer picture of the effects of solar shade on dairy cows. Future research on solar systems in a pasture dairy system should explore the economic effects of the solar system as well as long-term effects on milk production, reproductive performance, BW, and fat plus protein.

\section{ACKNOWLEDGMENTS}

The authors express gratitude to the livestock managers and farm animal attendants at the West Central Research and Outreach Center (Morris, MN) for their care of livestock. The authors also thank Anna Vold, Joanna Moser, Allison Bot, and Glenda Pereira, University of Minnesota West Central Research and Outreach Center (Morris, MN), for the hours they assisted in data collection. The funding for this project was provided by the Minnesota Environment and Natural Resources Trust Fund as recommended by the Legislative-Citizen Commission on Minnesota Resources (LCCMR). The authors have not stated any conflicts of interest.

\section{REFERENCES}

Allen, J. D., L. W. Hall, R. J. Collier, and J. F. Smith. 2015. Effect of core body temperature, time of day, and climate conditions on behavioral patterns of lactating dairy cows experiencing mild to moderate heat stress. J. Dairy Sci. 98:118-127. https://doi.org/10 $.3168 /$ jds.2013-7704.

Allen, M. R., O. P. Dube, W. Solecki, F. Aragón-Durand, W. Cramer, S. Humphreys, M. Kainuma, J. Kala, N. Mahowald, Y. Mulugetta, R. Perez, M. Wairiu, and K. Zickfeld. 2018. Framing and Context. Pages 49-91 in Global Warming of $1.5^{\circ} \mathrm{C}$. An IPCC Special Report on the Impacts of global warming of $1.5^{\circ} \mathrm{C}$ above pre-industrial levels and related global greenhouse gas emission pathways, in the context of strengthening the global response to the threat of cli- mate change, sustainable development, and efforts to eradicate poverty. https://www.ipcc.ch/sr15/.

Ammer, S., C. Lambertz, and M. Gauly. 2016a. Comparison of different measuring methods for body temperature in lactating cows under different climatic conditions. J. Dairy Res. 83:165-172. https:/ /doi.org/10.1017/S0022029916000182.

Ammer, S., C. Lambertz, and M. Gauly. 2016b. Is reticular temperature a useful indicator of heat stress in dairy cattle? J. Dairy Sci 99:10067-10076. https://doi.org/10.3168/jds.2016-11282.

Becker, C. A., R. J. Collier, and A. E. Stone. 2020. Invited review: Physiological and behavioral effects of heat stress in dairy cows. J. Dairy Sci. 103:6751-6770. https://doi.org/10.3168/jds.2019-17929.

Becker, C. A., and A. E. Stone. 2020. Graduate student literature review: Heat abatement strategies used to reduce negative effects of heat stress in dairy cows. J. Dairy Sci. 103:9667-9675. https://doi .org/10.3168/jds.2020-18536.

Bohmanova, J., I. Misztal, and J. B. Cole. 2007. Temperature-humidity indices as indicators of milk production losses due to heat stress. J. Dairy Sci. 90:1947-1956. https://doi.org/10.3168/jds.2006-513.

Chen, J. M., K. E. Schütz, and C. B. Tucker. 2015. Cooling cows efficiently with sprinklers: Physiological responses to water spray. J. Dairy Sci. 98:6925-6938. https://doi.org/10.3168/jds.2015-9434.

Cook, N. B., R. L. Mentink, T. B. Bennett, and K. Burgi. 2007. The effect of heat stress and lameness on time budgets of lactating dairy cows. J. Dairy Sci. 90:1674-1682. https://doi.org/10.3168/ jds.2006-634.

Dougherty, C. T., F. W. Knapp, P. B. Burrus, D. C. Willis, and P. L. Cornelius. 1994. Moderation of grazing behavior of beef cattle by stable flies (Stomoxys calcitrans L.). Appl. Anim. Behav. Sci 40:113-127. https://doi.org/10.1016/0168-1591(94)90076-0.

Dougherty, C. T., F. W. Knapp, P. B. Burrus, D. C. Willis, and P. L. Cornelius. 1995. Behavior of grazing cattle exposed to small populations of stable flies (Stomoxys calcitrans L.). Appl. Anim. Behav. Sci. 42:231-248. https://doi.org/10.1016/0168-1591(94)00546-Q.

Drwencke, A. M., G. Tresoldi, M. M. Stevens, V. Narayanan, A. V. Carrazco, F. M. Mitloehner, T. E. Pistochini, and C. B. Tucker. 2020. Innovative cooling strategies: Dairy cow responses and water and energy use. J. Dairy Sci. 103:5440-5454. https://doi.org/10 .3168/jds.2019-17351.

Dupraz, C., H. Marrou, G. Talbot, L. Dufour, A. Nogier, and Y. Ferard. 2011. Combining solar photovoltaic panels and food crops for optimizing land use: Towards new agrivoltaic schemes. Renew. Energy 36:2725-2732. https://doi.org/10.1016/j.renene.2011.03.005.

García-Ispierto, I., F. López-Gatius, P. Santolaria, J. L. Yániz, C. Nogareda, M. López-Béjar, and F. De Rensis. 2006. Relationship between heat stress during the peri-implantation period and early fetal loss in dairy cattle. Theriogenology 65:799-807. https://doi .org/10.1016/j.theriogenology.2005.06.011.

Hahn, G. L., A. M. Parkhurst, and J. B. Gaughan. 1997. Cattle respiration rate as a function of ambient temperature. ASAE Paper No. MC97-121. American Society Agricultural Engineers, St. Joseph, MI.

Hassanpour Adeh, E., J. S. Selker, and C. W. Higgins . 2018. Remarkable agrivoltaic influence on soil moisture, micrometeorology and water-use efficiency. PLoS One 13:e0203256. https://doi.org/10 .1371 /journal.pone.0203256.

IPCC. 2007: Climate Change 2007: Impacts, adaptation and vulnerability. Page 976 in Contribution of Working Group II to the Fourth Assessment Report of the Intergovernmental Panel on Climate Change (IPCC). M. L. Parry, O. F. Canziani, J. P. Palutikof, P. J. van der Linden, and C. E. Hanson, ed. Cambridge University Press, Cambridge, UK.

Kendall, P. E., P. P. Nielsen, J. R. Webster, G. A. Verkerk, R. P. Littlejohn, and L. R. Matthews. 2006. The effects of providing shade to lactating dairy cows in a temperate climate. J. Livest. Sci. 103:148-157. https://doi.org/10.1016/j.livsci.2006.02.004.

Kendall, P. E., G. A. Verkerk, J. R. Webster, and C. B. Tucker. 2007. Sprinklers and shade cool cows and reduce insect-avoidance behavior in pasture-based dairy systems. J. Dairy Sci. 90:3671-3680. https://doi.org/10.3168/jds.2006-766. 
Kienitz, M. J., B. J. Heins, and R. D. Moon. 2018. Evaluation of a commercial vacuum fly trap for controlling flies on organic dairy farms. J. Dairy Sci. 101:4667-4675. https://doi.org/10.3168/jds .2017-13367.

Lefcourt, A. M., and E. T. Schmidtmann. 1989. Body temperature of dry cows on pasture: Environmental and behavioral effects. J. Dairy Sci. 72:3040-3049. https://doi.org/10.3168/jds.S0022 -0302(89)79457-1.

Littell, R. C., P. R. Henry, and C. B. Ammerman. 1998. Statistical analysis of repeated measures data using SAS procedures. J. Anim. Sci. 76:1216-1231. https://doi.org/10.2527/1998.7641216x.

Maia, A. S. C., E. A. Culhari, V. F. C. Fonsêca, H. F. M. Milan, and K. G. Gebremedhin. 2020. Photovoltaic panels as shading resources for livestock. J. Clean. Prod. 258:120551. https://doi.org/ 10.1016/j.jclepro.2020.120551.

Mullens, B. A., K.-S. Lii, Y. Mao, J. A. Meyer, N. G. Peterson, and C. E. Szijj. 2006. Behavioural responses of dairy cattle to the stable fly, Stomoxys calcitrans, in an open field environment. Med. Vet. Entomol. 20:122-137. https://doi.org/10.1111/j.1365-2915.2006 $.00608 . x$.

Muller, C. J., J. A. Both, W. A. Coetzer, and W. A. Smith. 1994. Effect of shade on various parameters of Friesian cows in a Mediterranean climate in South Africa. 2. Physiological responses. S. Afr. J. Anim. Sci. 24:56-60.

National Research Council. 1981. Effect of Environment on Nutrient Requirements of Domestic Animals. National Academies Press, Washington, DC.

Nienaber, J. A., G. L. Hahn, T. M. Brown-Brandl, and R. A. Eigenberg. 2003. Heat stress climatic conditions and the physiological responses of cattle. Pages 255-262 in ASABE Fifth International Dairy Housing Proceedings Conf., Fort Worth, TX. ASABE, St. Joseph, MI. https://doi.org/10.13031/2013.11629.

Palacio, S., R. Bergeron, S. Lachance, and E. Vasseur. 2015. The effects of providing portable shade at pasture on dairy cow behavior and physiology. J. Dairy Sci. 98:6085-6093. https://doi.org/10 $.3168 /$ jds.2014-8932.

Pereira, G. M., B. J. Heins, and M. I. Endres. 2018. Technical note: Validation of an ear-tag accelerometer sensor to determine rumination, eating, and activity behaviors of grazing dairy cattle. J. Dairy Sci. 101:2492-2495. https://doi.org/10.3168/jds.2016-12534.

Perttu, R. K., B. J. Heins, H. N. Phillips, M. I. Endres, R. D. Moon, and U. S. Sorge. 2020. Short communication: Effects of mesh leg- gings on fly pressure and fly avoidance behaviors of pastured dairy cows. J. Dairy Sci. 103:846-851. https://doi.org/10.3168/jds.2019 $-17267$.

PVWatts. 2019. PVWatts Calculator. Accessed Feb. 6, 2020. https:// pvwatts.nrel.gov/pvwatts.php.

Reneau, J. K., A. J. Seykora, B. J. Heins, M. I. Endres, R. J. Farnsworth, and R. F. Bey. 2005. Association between hygiene scores and somatic cell scores in dairy cattle. J. Am. Vet. Med. Assoc. 227:1297-1301. https://doi.org/10.2460/javma.2005.227.1297.

SAS Institute. 2016. SAS/STAT Software. Release 9.4. SAS Institute Inc., Cary, NC.

Schütz, K. E., A. R. Rogers, N. R. Cox, and C. B. Tucker. 2009. Dairy cows prefer shade that offers greater protection against solar radiation in summer: Shade use, behaviour, and body temperature. Appl. Anim. Behav. Sci. 116:28-34. https://doi.org/10.1016/ j.applanim.2008.07.005.

Sjostrom, L. S., B. J. Heins, M. I. Endres, R. D. Moon, and U. S. Sorge. 2019. Effects of winter housing system on hygiene, udder health, frostbite, and rumination of dairy cows. J. Dairy Sci. 102:10606-10615. https://doi.org/10.3168/jds.2018-15759.

St-Pierre, N. R., B. Cobanov, and G. Schnitkey. 2003. Economic losses from heat stress by US livestock industries. J. Dairy Sci. 86:E52E77. https://doi.org/10.3168/jds.S0022-0302(03)74040-5.

Tucker, C. B., A. R. Rogers, and K. E. Schütz. 2008. Effect of solar radiation on dairy cattle behavior, use of shade and body temperature in a pasture-based system. Appl. Anim. Behav. Sci. 109:141154. https://doi.org/10.1016/j.applanim.2007.03.015.

USDA-NOP. 2019. The program handbook: Guidance and instructions for accredited certifying agents and certified operations. Accessed Feb. 2020. https://www.ams.usda.gov/about-ams/programs -offices/national-organic-program.

West, J. W. 2003. Effects of heat stress on production in dairy cattle. J. Dairy Sci. 86:2131-2144. https://doi.org/10.3168/jds.S0022 -0302(03)73803-X.

\section{ORCIDS}

B. J. Heins @ https://orcid.org/0000-0003-2186-9082

M. H. Reese () https://orcid.org/0000-0001-6362-8805 